\title{
K novým cestám Hlbinovej poézie Peter Tollarovič
}

\author{
TOLLAROVIČ, P.: On New Ways of Hlbina's Poetry \\ SLOVENSKÁ LITERATÚRA 68, 2021, No. 1, p. 19-39 \\ DOI: https://doi.org/10.31577/slovlit.2021.68.1.2 \\ ORCID ID: https://orcid.org/0000-0002-2214-1993
}

\begin{abstract}
Key words: Pavol Gašparovič Hlbina, Catholic Modernism, Slovak poetic avant-garde, poetism, surrealism, pure poetry
\end{abstract}

The paper deals with the poetry of Pavol Gašparovič Hlbina written in the second half of the 1930s, when the author was one of the most productive Slovak poets, reviewers, translators, and literary aestheticians. It traces the causes of changes in his poetics used especially in the collection of poems Dúha (The Rainbow, 1937) as well as his relations to his close collaborator Rudolf Dilong (1905-1986), mainly in the context of their editorial activities in the magazines associated with Catholic Modernism (Postup and Prameñ). It outlines the author's poetry in the context of Slovak modification of poetism and maps his views on surrealism. When the collection Dúha (The Rainbow, 1937) was published, Hlbina was closely following the rising surrealist tendencies in the Slovak literary environment and writing numerous reflections on them. This collection of poems also represents the modern variant of his poetry. The other variant is religious poetry; this type of poetics was used when cooperating on an extensive project of St Adalbert Association, which was the Unified Catholic Hymnbook published in 1937.

Klúčové slová: Pavol Gašparovič Hlbina, katolícka moderna, slovenská básnická avantgarda, poetizmus, surrealizmus, čistá poézia

oci prvé dve básnické zbierky Pavla Gašparoviča Hlbinu (1908 - 1977) vydané v rokoch 1932 (Začarovaný kruh) a 1933 (Cesta do raja) nemali charakter manifestu, v polovici tridsiatych rokov 20. storočia sa básnik stal autoritou a bol považovaný za iniciátora a priekopníka katolíckej moderny v slovenskom literárnom kontexte. Aj literárny historik Július Pašteka označil Hlbinu za nádejného skupinového teoretika a literárneho kritika (Pašteka 2002:49), a to napriek tomu, že zostavovatel'om Antológie mladej slovenskejpoézie (1933), ktorou sa nové autorské zoskupenie prezentovalo, bol Rudolf Dilong. Oficiálnou Hlbinovou 
funkciou bolo redigovanie mesačníka Postup ihned' od začiatku jeho vydávania, teda od januára 1934. Ako redaktori boli uvádzaní okrem Hlbinu a Dilonga ešte Štefan Atila Brezány, L'udo Ondrejov, Koloman Geraldini, Ivan Minárik a Ján Mora. Redakciu však viedli najmä Hlbina s Dilongom. Už rok predtým Dilong inicioval knižnú edíciu Postup, v rámci ktorej ihned' rátal s Hlbinovou zbierkou Cesta do raja. Ambíciou bolo vydat pät kníh poézie a pät kníh prózy. Prózu mal mat' na starosti Brezány. V čase, ked' Dilong listom oslovoval Hlbinu, plánoval do edície zaradit' ešte zbierky Ivana Javora, Františka Hečka, Jána Harantu, Kolomana Geraldiniho a možno Borina. ${ }^{1}$ Zo spomínaných autorov napokon vyšla iba Hlbinova Cesta do raja a Harantov debut Mystérium baladické. Do konca roka 1935 vyšlo v edícii trinást' kníh, no namiesto menovaných básnikov do nej boli zaradené zbierky Alexandra Pogorielova Verše o stratených (1934) a Lubomíra Kupčoka Haviari (1934). S básnikmi okolo časopisu Postup a rovnomenného knižného radu nebola spokojná ani literárna kritika a ani sám Hlbina. Ten dokonca protestoval voči Brezányho redaktorskému pôsobeniu. Dilong ho musel v liste presviedčat', že ho nemožno obíst vzhl'adom na jeho zásluhy: založenie literárnej družiny v roku 1927, iniciovanie Almanachu tretejliterárnej generácie (1930) a aj založenie samotnej edície Postup. ${ }^{2}$

\section{Peripetie s časopisom Postup}

Časopis Postup a jeho knižná edícia vzbudili dostatok pozornosti a Dilong a navonok i Hlbina boli s výsledkom v podstate spokojní. Už v tretom čísle časopisu sa však objavil oznam o zmene redakcie: „Boli sme nútení zmenit' redakciu, však nie z osobných vecí. Dilong a Hlbina zostanú i nad'alej našimi hlavnými spolupracovníkmi“ “(Zmena redakcie, 1934). J. Pašteka na margo zastavenia ich aktívneho redakčného pôsobenia uviedol: „Zrejme obaja menovaní nemohli ako katolícki kňazi redigovat' necirkevný časopis, ani sa aktívne zúčastňovat' na ideovom propagovaní postupistickej družiny, zloženej z vel'mi rôznorodých členov“" (Pašteka 2002: 49). Hlbina poznal prispievatel'ov a ich názory, ked'že bol členom redakcie a udržiaval s nimi kontakty. V skutočnosti však nadriadení bránili iba Dilongovi a ten so sebou stiahol aj Hlbinu. V liste z februára $1934 \mathrm{mu}$ Dilong písal: „Ukrižovali Teba, ukrižovali i mňa. Spolok Sv. Vojtecha, tá hanba, ten vred na tele kultúrneho Slovenska, sa zas rozhadzuje. Napísali list môjmu provinciálnemu predstavenému. “3 Dilong odporúčal Hlbinovi, aby sa z redaktorstva stiahol i on: „A myslím, žeby bolo dobre vynechat' aj Teba z red. kruhu, lebo potom Ty budeš terčom ich zášti. Tým lepšie bude pre nás, ked'bude časopis (tobôž redakcia) od nás klerikov čistá. “4 Dilongova dikcia je vo vztahu k Hlbinovi značne manipulatívna. Niektoré Hlbinove poznámky na listoch od Dilonga svedčia o tom, že z nich nebol nadšený. Dilongovo prehováranie vrcholí v závere citovaného listu: „A zdel'mi i o sebe, či si praješ d'alej ostat' uvedený v red. kruhu, či nie. Ja Ti vel'mi odporúčam, ba až prosím Ťa, aby sme Ťa nahradili iným.“5

1 R. Dilong v liste P. G. Hlbinovi, 1933, bez bližšieho datovania. Slovenská národná knižnica v Martine, Literárny archív (d'alej LA SNK), osobný fond P. G. Hlbina, sign. 169 A 26.

2 R. Dilong v liste P. G. Hlbinovi, 18. november 1933. LA SNK, osobný fond P. G. Hlbina, sign. 169 A 26.

3 R. Dilong v liste P. G. Hlbinovi, 26. február 1934. LA SNK, osobný fond P. G. Hlbina, sign. 169 A 26.

4 R. Dilong v liste P. G. Hlbinovi, 26. február 1934. LA SNK, osobný fond P. G. Hlbina, sign. 169 A 26.

5 R. Dilong v liste P. G. Hlbinovi, 26. február 1934. LA SNK, osobný fond P. G. Hlbina, sign. 169 A 26. 
Hlbina nakoniec tieto odporúčania a prosby poslúchol, ved'ako rozvážny klerik, ktorého od vytúženej kňazskej vysviacky delil už iba polrok (kňazskú vysviacku prijal 3o. septembra 1934), pravdepodobne nechcel riskovat', hoci jeho priatel' Jozef Kútnik-Šmálov mu to vyčítal ako nepredvídavé a unáhlené rozhodnutie: „Prečo si vystúpil z redakcie Postupu? R. Dilongovi prištipli akiste palce. Počul som od vážnych činitel'ov lamentácie, že on klérus škandalizuje. Nad ním vraj aj nad Javorom. Akosi zavčasu. Neviem, neviem, ako bude s tou kat. modernou. Aby jej len zavčasu neodzvonili. “6 Hlbinove odpovede sa síce nezachovali, no i tak možno rekonštruovat' proces jeho odmlčania sa v časopise Postup.

Dilong „bratsky“ radil Hlbinovi, aby odstúpil z redakcie a nestal sa predmetom nevraživosti. Nakoniec obavy cirkevných predstavitel'ov v prípade Dilonga i Javora potvrdil čas. Dilongov príbeh je známy a Javor dokonca vystúpil z kňazstva. Dilongova snaha o ovplyvňovanie Hlbinu je zrejmá. Okrem iného ho prehováral, aby vstúpil k nemu do františkánskej rehole a nedal sa vysvätit' pre Nitriansku diecézu, čím v ňom vyvolával d'alšie rozpaky.

Po týchto negatívnych skúsenostiach sa Hlbina opät sústredil na Elán redigovaný Jánom Smrekom, s ktorým sa dohodol aj na vydaní svojej nasledujúcej zbierky Harmonika (1935). Smrek ho privítal vel'mi srdečne: „Elán má na Vás právo. Knihu Vám, samozrejme, vydáme. Ráčte poslat rukopis, náhle ho budete mat pripravený. Urobíme Vám peknú knižku. Mám teraz najlepšie tlačiarne. “7 Harmonika sa tak stala prvou Hlbinovou zbierkou, ktorej proces knižného publikovania sa zaobišiel bez predošlých komplikácií.

K osvetleniu Hlbinovho básnického vývinu v zbierkach Dúha (1937) a Belasé výšky (1939) je potrebné vrátit' sa k udalostiam sprevádzajúcim vydávanie časopisu Postup. Niečo ozrejmuje aj Hlbinova odpoved'a v kontexte uvedených skutočností i jeho ojedinelý príspevok v septembrovom čísle časopisu Postup v roku 1934. V odpovedi na Anketu o poézii, čo bola jedna z rubrík časopisu, už vníma poéziu trochu inak než vo svojich predošlých teoretických statiach: „Poézia je hra a nič viac, ani menej“ (Hlbina 1934a). Výrok sa stane emblematickým a charakteristickým pre zbierku Dúha. Túto myšlienku d'alej spresňoval pomocou príkladu: „Kto verí v absolútnu hodnotu slovného a ideového materiálu v básni, pripomína lakomca, ktorý verív absolútnu hodnotu peňazí. A takých lakomcov je mnoho, ktorí si poplietli evokačný prostriedok v básni s vlastnou poéziou. Tak potom miesto poézie píšu rétorské šlágre, ktorými by chceli spasit' sociálne ubiedených“ (Hlbina 1934a).V čase uverejnenia týchto úvah jednak polemizoval s Dilongom, ktorý má vo svojej zbierke Hviezdy a smútok (1934) podobné básne (Neznámy, Hraj, cigáñ, Bedársky dnešok), a tiež s l'avicovo orientovanými postupistami Pogorielovom, Kupčokom a Markom. Tí si čiastočne osvojili náboženské reálie blízke autorom katolíckej moderny, no s krestáanstvom polemizovali, čo Hlbina, v prípade Pogorielova a prozaika Jána Letka, aj kritizoval. Stažoval sa redaktorovi Postupu Atilovi Brezánymu, ktorý mu potom odpovedal: „Príspevky, o ktorých píšete, že boli po stránke mravnej a náboženskej závadné, prešli i Rudovou rukou a ten ich plne schválil. Je pravda, že tá báseň Pogorielova je nábožensky chybná, však vec toho

6 J. Kútnik-Šmálov v liste P. G. Hlbinovi, 14. apríl 1934. LA SNK, osobný fond P. G. Hlbina, sign. 169 C 32.

7 J. Smrek v liste P. G. Hlbinovi, 21. december 1934. LA SNK, osobný fond P. G. Hlbina, sign. 169 E 19. 
22 Letka mne nezdá sa byt' tak zlá, aj Rudo ju chválil, ba ešte nechal tam to, čo som ja vyškrtnul. "8 I ked'Hlbinov list nie je známy, dá sa predpokladat', že mu prekážala Pogorielovova báseň Júnový dážd'zo štvrtého čísla prvého ročníka Postupu: „A zdá sa mi, akoby Spasitel' / kráčal cez dážd', / díval sa na mňa vodným páperím. / Ach, načo, Pane, takéto zjavy? / Ved'ja už dávno / neverím. / Je to len púha imaginácia / fantázia“" (Pogorielov 1934). Ján Letko zasa uverejnil ukážku filmového scenára, ktorý nazval Tančiaca spravedlivost', s podtitulom fantasticko-dokumentárny film. V ňom asi Hlbinovi nesadol úryvok: „Láska stvorila nesmrtelné hodnoty. Laboratórium. Pod drobnohl'adom v mikroskopickom skielku hemžia sa syfilitické bacily. To je tiež dielo lásky" (Letko 1934). Deklaratívne a jednoduché zapieranie viery a kvázi erotický motív viedli Hlbinu k pomerne príkremu hodnoteniu časopisu, a to navyše v čase, ked'už nebol jeho redaktorom. Ak Brezány v liste argumentuje Rudom, teda Dilongom, domnievam sa, že takéto literárne prejavy uverejňoval Dilong v Postupe zámerne ako provokáciu. Aj J. Pašteka po rokoch konštatoval: „P. G. Hlbina mal lepšie predpoklady [ako Ján Elen Bor, o ktorom hovorí predtým, pozn. P. T.] stat' sa ideovým vodcom a kritickým exponentom rodiacej sa katolíckej moderny. Mesačník Postup mohol mu tak poslúžit ako názorová tribúna, keby nebol musel vystúpit' z redakcie“ (Pašteka 2002:57). Hlbina musel odíst', lebo ho so sebou stiahol Dilong. Aj z dôvodu predstavených príspevkov Pogorielova a Letka a viacerých podobných, od ktorých sa Hlbina sám dištancoval, už časopis nebol viac preňho názorovou tribúnou, o ktorej sa zmieňuje J. Pašteka. Časopis Postup tak bez Hlbinu a s pridanou hodnotou provokujúcich príspevkov stratil ráz platformy rodiacej sa slovenskej katolíckej moderny.

\section{Časopis Prameň ako nová nádej}

Problematické pôsobenie v časopise a nespokojnost' s jeho vývinom boli medzi dôvodmi skorej zmeny Hlbinovej poetiky, ked’že spirituálna lyrika v prostredí literárnych časopisov na krátky čas, až do príchodu Janka Silana a Pala Olivu, upadla. Práve Hlbina predstavil slovenskej verejnosti Janka Silana, vtedy ešte pomerne neznámeho básnika, ked'v októbri 1936 recenzoval jeho debutovú zbierku Kuvici (1936), vydanú v Čechách nákladom Fondu Julia Zeyera pri Českej akadémii vied a umení. Recenziu uverejnil v časopise Prameň, ktorý bol po zániku Postupu považovaný za časopis autorov okruhu slovenskej katolíckej moderny. Tento časopis bol na rozdiel od Postupu „očistený“ od l'avicových a nie príliš presvedčivých básnikov Pogorielova, Kupčoka či Marka. Odídencov nahradili talentovanejší a navyše spirituálne ladení tvorcovia-Svetloslav Veigl, Helena Riasnická či Henny Fiebigová, ktorá bola vtedy už častou Hlbinovou korešpondentkou. ${ }^{9}$ Hlbinovi očividne lichotilo, že v Silanových básňach pozoroval ozveny svojich vlastných veršov: „Silan pozná dobre súčasnú veršovú techniku, jeho rytmus je zvonivý a mnohotvárny, rým väčšinou zvučný. Miestami na prvý pohl'ad zbadá čitatel', kde sa Silan priúčal básnickej faktúre (Lukáč, Hlbina, Dilong), ale básnický zážitok má všade svoj vlastný“ (Hlbina 1936c). Hlbina oceňuje veršovú techniku a rým, čo treba interpretovat'v kontexte jeho odporu voči Fabryho poézii a surrealistickej

8 A. Š. Brezány v liste P. G. Hlbinovi, 12. máj 1934. LA SNK, osobný fond P. G. Hlbina, sign. 169 A 15.

9 Tieto listy analyzovala Andrea Bokníková v antológii Potopené duše, kde tiež uvádza, že práve Hlbina poradil H. Fiebigovej básnický pseudonym Stela Rajská, ktorý si však neosvojila (Bokníková 2017: 147). 
básnickej technike vôbec. Inšpiráciu, no nie závislost'od jeho vlastnej či Dilongovej poézie pozoruje ako pozitívny a nenásilný prvok. Prostredníctvom kladného hodnotenia Silanovej zbierky nielenže ako prvý upriamil pozornost' na jeho prvotinu, no najmä vysoko ocenil jeho prínos ako mladého spirituálneho básnika, o ktorom vedel, že „síce mu slabne zrak telesný, ale otvára sa pri tom zrak duchovný a intuícia“" (Hlbina 1936c).

\section{Hlbinova recepcia zbierky Rudolfa Fabryho Utaté ruky}

Hoci redaktorom Prameňa bol básnik, prekladatel'a literárny kritik Koloman Geraldini, hodnotenie básnických zbierok, ktoré boli už vtedy vnímané ako prelomové, prenechal Hlbinovi. Takouto bola v kontexte slovenskej katolíckej moderny práve Silanova zbierka Kuvici. Ako sa neskôr ukázalo, nielen podla Hlbinu. Ešte väčším medzníkom boli Fabryho Ut'até ruky. Aj tie na stránkach Prameňa čitatel'om predstavil Hlbina. Jeho posudok vyznel vel'mi negatívne. Čuduje sa, že básnici ako Emil Boleslav Lukáč, Laco Novomeský či Andrej Žarnov sa nechali nahovorit' a napísali pár viet na reklamný leták k tejto zbierke, v ktorej podl'a neho nie je nič nové okrem peknej typografie a grafickej úpravy knihy. Inak zbierku hodnotí ako „prázdne tláchanie, bohapusté nivelizovanie všetkých duchovných hodnôt, fumigovanie tvaroslovných a rytmických zákonov, miešanie náboženských konceptov do pomyjí najhnusnejších oplzlostí“ (Hlbina 1936d). Hlbina bol na paškvilizáciu náboženstva vel'mi citlivý. V Utáatých rukách je viacero takýchto básní (zástupne napr. Sekvencie ku cti 14-ročnej malomocnej), ktoré možno charakterizovat' citovanými Hlbinovými slovami. Napriek tomu Fabrymu neodopiera talent: „Nemožno povedat', že by Fabry nemal básnického nadania, nájdu sa v zbierke partie čistej poézie, ale práve jeho násilný surrealizmus ho zvádza k prázdnemu hromadeniu exotických slov: len aby sa povedalo, že je surrealista a moderný“ (Hlbina 1936d). Z úryvku možno opät' vyčítat' Hlbinovo pohŕdanie modernostou, čo naznačil už v úvodnej básni zbierky Cesty do raja (1933) s názvom O nový verš. Ak vo Fabryho zbierke nachádza „partie čistej poézie“, má pravdepodobne na mysli básne z preškrtnutého Prológu, pretože poslednú čast' zbierky Fair play vyhodnotil tak, že nemá nič spoločné s umením (Hlbina 1936d). Formulka používaná občas v dnešných periodikách, že ,názory autorov nie sú názormi redakcie“, sa v danom období v slovenských časopisoch nevyskytovala. Aspoň nie v Prameni. Prispievatelia zastávali svoj časopis a v tejto jednote spoločne obraňovali svoje umelecké výstupy pred inými periodikami, napr. Slovenskými smermi. Potom možno povedat', že obdobný názor na slovenský surrealistický debut zastávala väčšina prispievatel'ov časopisu. Koniec koncov, Hlbina recenziou radikálne neodmietol surrealizmus sám osebe, zavrhol iba Fabryho prejav, čo náležite odôvodnil. Je trochu paradoxné, že prichádzajúci básnici P. Oliva, S. Veigl a tiež H. Fiebigová surrealizmus nezavrhli, práve naopak. V ich tvorbe je prítomný v takej podobe, ktorá spíňa Hlbinove poetologické kritériá. Mladí talentovaní básnici, ktorí surrealizmus, resp. neskôr slovenský nadrealizmus vnímali spoločne s Hlbinom, ako boli Vojtech Mihálik, Miroslav Válek a Viliam Turčány, nastúpili až o desatročie neskôr. Prvý z nich bol „bojovníkom proti modernej poézii“, teda nadrealizmu, Turčány zasa ako polemiku vyhlásil nový literárny smer podrealizmus. V tomto kontexte je to vlastne o desatročie oneskorená reakcia na Hlbinov postoj k Fabryho nástupu, reakcia mladej generácie, ktorú s nádejou očakával už vtedy, i ked' 
spomenutá trojica básnikov Hlbinovu recenziu zrejme nečítala. Neprekvapuje preto, že Hlbinova poézia bola pre V. Mihálika, M. Válka a V. Turčányho akýmsi „žriedlom“, čo možno demonštrovat' na viacerých príkladoch. Hlbina zamýšlal svoje antipatie voči Fabryho tvorbe uverejnit už v prvej polovici roka 1935 v Eláne. Šéfredaktor J. Smrek však jeho kritiku odmietol: „Článok proti Fabrymu Vám musím vrátit'. Predovšetkým Fabry ešte nie je taký dôležitý, aby ste sa museli preňho tak rozčul'ovat' - a vy sa aj naozaj rozčulujete tak, že tento štýl nemôžeme v Eláne pestovat'. Sú to výrazy ako: chlapík, soplavý nafúkanec, to je volovina, soplaví chasníci atd.' "10 Len na okraj možno dodat', že práve v tom čase vyšla v Smrekovej Edícii mladých slovenských autorov Hlbinova nová zbierka Harmonika.

\section{Nezhody s bratom Dilongom}

Jednou z mnohých nezhôd medzi Dilongom a Hlbinom bola Dilongova finančná podpora Fabryho zbierky. Dilong sa tiež zúčastnil predstavenia Ut'atých rúk verejnosti a prvého stretnutia surrealistov v Trnave začiatkom januára 1936. V nastávajúcom období sa začalo ich vzájomné súperenie v modernosti. Hlbina nasledujúcou zbierkou Dúha (1937) vzdal de facto hold poetizmu a Dilong zbierkou Mladýsvadobnik (1936) zasa surrealizmu, pričom na najbližšie roky sa stal členom slovenskej nadrealistickej skupiny, čo dokazoval i d'alšími zbierkami. Ich vzájomné dot'ahovanie miestami vyznieva komicky. Hlbina sa koncom roka 1937, čerstvo po vydaní zbierky Dúha, vystatoval v liste Dilongovi, že už má do tlače nachystanú d'alšiu zbierku. Najprv sa však stažoval na svoje nové kaplánske pôsobisko:

„Ako už vieš, aj ja som už presídlil z jednej diery do druhej. Ale básnik si všade vytvorí svoje královstvo. Zlá zelina nevyhynie a všade pustí korene. Píšeš mi, že aj Ty ideš vydat' knihu. Mohol bys mi napísat', kde ju vydávaš. I ja mám zas pripravenú vel'mi peknú zbierku, ale neviem, kde ju vydat'. Na každý pád sa musíme usilovat', aby sme my dvaja boli najväčší básnici na svete. Porad' mi, kde tú novú knihu vydat'. Už mi toho roku tuším zbýva len Urbánek. Kde si vzal tú Jawu? Posledné číslo Prameňa bolo vel'mi slabé. Musíme sa pousilovat'ho omladit'. Dávate tam také všelijaké haraburdy o Valašskej škole mravov stodole, neviem koho to zaujíma. Ani o Pekařovi ste tam nemuseli tol'ko dávat'. My sme mladí a musíme hýrit' mladostou. "11

Pre pochopenie vtedajšej situácie oboch básnikov je tento rozsiahlejši úryvok Hlbinovho listu mnohovravný. Hlbina ešte nie je deprimovaný častým prekladaním do nelukratívnych farností (čo sa čoskoro zmenilo). Svoju nelichotivú situáciu berie s humorom. V očakávaní priaznivých recenzií Dúhy už uvažuje o vydaní Belasých výšok, hoci knižka vyšla až o viac než rok. Hlbinova výzva, aby s Dilongom boli „najväčší básnici na svete“, je síce úsmevná, no obaja naozaj prežívali vrchol tvorivého vzopätia a uznania. Hlbina v liste spomína známu Dilongovu motorku Jawa, ktorú si kúpil za štedrý honorár za zbierku Mladý svadobník. ${ }^{12} \mathrm{~V}$ každom

10 J. Smrek v liste P. G. Hlbinovi, 16. apríl 1935. LA SNK, osobný fond P. G. Hlbina, sign. 169 E 19.

11 P. G. Hlbina v liste R. Dilongovi, 11. november 1937. LA SNK, osobný fond P. G. Hlbina, sign. 77 A 14.

12 Podrobnosti ku kúpe motorky uviedol Marián Kamenčík v monografii o Dilongovi, mapujúcej obdobie jeho pôsobenia v Hlohovci (Kamenčík 2019: 111). 
prípade Dilongova popularita bola na vzostupe. Hlbina sa po spore s Rudolfom

Brtáňom plánoval ozvat' novou poetikou práve v novej zbierke Dúha. V závere kritizuje - v kontexte profilácie časopisu Prameň ako časopisu pre modernú literatúru celkom oprávnene - sériu článkov na pokračovanie o Hugolínovi Gavlovičovi z pera Jozefa Paldiu a články Jána Meštančíka o historikovi Josefovi Pekařovi.

Dilongova štýlová odpoved'bola blesková a rovnako neskromná. Takisto začína vystatovaním, že vydáva knihu v Matici slovenskej, dokonca na žiadost' Andreja Mráza. V skutočnosti mu kniha v Matici slovenskej najbližšie štyri roky nevyšla, až v roku 1941 zbierka Konvália. Zrejme chcel Hlbinu iba podpichovat' a zbavit' ho pocitu istej exkluzivity, ked'že jemu v Matici práve vyšla Dúha. Dilong tiež Hlbinovi radil, kde by mohol vydat' svoju plánovanú zbierku:

„Ja Ti môžem radit' troje: 1 . Spolok sv. Vojtecha v edícii ,Poézia‘ už vydal jedno číslo - Hohošove básne, oprobuj, tam si im predsa pracoval, mohli by Ti vydat'. 2. Urbánek v edícii ,Prameň ' Ti môže tiež vydat', už od Helena nosí l'aliu sú dva roky, tak tam môžeš sa dostat'. 3. Aligátor, lenže háčik je v tom, že Aligátor má svojho nakladatel'a v osobe básnika, ktorý tam vydáva a je to oštara a starost' s odpredajom. No ale Ty si bohatý kaplán, nuž ako chceš. Konečne je tu Mazáčov súbeh, platí tuším do Vianoc t. r., prvá cena 15 ooo chlape! Verím, že my dvaja budeme vel'kí, ale len pre potomstvo, nateraz stačí, že jedon z nás, to jest ja, je avantgardným básnikom Slovenska."13

Odporúčanie Spolku sv. Vojtecha bolo z Dilongovej strany provokáciou, pretože v spolkovej edícii Poézia vyšla dovtedy iba podpriemerná lyrika Ladislava Hohoša Cestou baladickou (1936). Aj narážka na Ferka Urbánka je uštipačná v tom zmysle, že od vydania Dilongovej zbierky Helena nosí l'aliu (1935) už ubehli dva roky, takže by sa mohol u tohto vydavatel'a prípadne naskytnút priestor aj pre Hlbinovu zbierku. Cenné je objasnenie fungovania edície Aligátor, ked'že už publikujúci autori ${ }^{14}$ si v nej zbierky hradili sami, resp. s Dilongovou finančnou podporou, za čo mu boli potom zaviazaní. Hlbina však bohatým kaplánom nebol. Dilong reagoval aj na Hlbinovu poznámku o ich spoločnej ceste, aby boli obaja „najväčšími“ “básnikmi.Za „vel'kého avantgardného básnika Slovenska“ pasoval však iba seba, čo sa Hlbinu očividne dotklo, ked'že si túto vetu v liste podčiarkol červeným perom a dopísal poznámku: „Dilong je drzý! Odteraz mám s ním pokoj!"15 Hoci z korešpondencie medzi Hlbinom a Dilongom sa v celosti zachovali iba listy adresované Hlbinovi, tento ojedinelý príklad, kde máme k dispozícii vyjadrenia oboch strán, naznačuje mnohé. Jednak dokladuje a potvrdzuje priatel'ský vzt'ah, ale zároveň aj citel'nú rivalitu, a objasňuje mnohé reálie a okolnosti, ktoré mali vplyv na básnickú tvorbu oboch protagonistov.

13 R. Dilong v liste P. G. Hlbinovi, 9. november 1937. LA SNK, osobný fond R. Dilong, sign. 169 A 26.

14 Rudolf Fabry, Móric Mittelmann Dedinský: Krivky (1936) a potom opät' Rudolf Fabry: Vodnéhodiny, hodiny piesočné (1938), Vladimír Reisel: Vidím všetky dni a noci (1939) a napokon Ivan Kunoš: Podl'a hviezd menit'masky (1940).

15 R. Dilong v liste P. G. Hlbinovi, 9. november 1937. LA SNK, osobný fond R. Dilong, sign. 169 A 26. 


\section{Surrealizmus à la Hlbina}

Druhý ročník Prameňa, ktorý zároveň uzavrel vydávanie časopisu, priniesol ako posledný pôvodný básnický text surrealisticky ladenú báseň Pal'a Olivu Panne. Neskôr ju autor zaradil do svojej jedinej básnickej zbierky Oblaky (1939), kde sa stala prvou častou rozsiahlejšieho cyklu Madone. Oliva v nej využíva metódu vol'ných asociácií a tiež litanickost'. Oboje v hojnej miere nachádzame aj u Fabryho, ku ktorému bol Hlbina kritický. Oliva adoruje Pannu Máriu: „Keby sa Tvoje dlane podobali viničovým listom / Tvoje dlane bez rán / Tvoje dlane Kvety, ktorév noci rozkvitli / Keby sa Tvoje dlane podobali viničovým listom / Tvoje dlane nad Franciou nad nami a nad celým svetom / Tvoje dlane dva oblaky svetiel / Tvoje dlane sila La Saletty / Keby sa Tvoje dlane podobali viničovým listom / Aby ich mohli pobozkat'i deti“ (Oliva 1937). Citované verše sú ukážkou modernej poézie podl'a Hlbinových kritérií a nárokov. Aj s Olivom si vymenil zopár listov. Isto nie náhodou bola pri publikovaní Olivovej básne Panne v časopise Prameň uverejnená na náprotivnej strane Hlbinova krátka posmešná báseň Surrealistické zátišie, ktorú potom zaradil i do zbierky Belasé výšky (1939): „Láska znie v speve slávičom / a básnik skryl sa do slova. / Spieva a nevie o ničom / mystická hlava oslova" (H1bina 1937b). V citovanej druhej strofe zhrnul svoje výhrady voči surrealistickej poézii: básnik sa skrýva, teda nie je prítomný, básnická individualita sa nemôže preukázat', absentuje vlastný básnický výraz a čistota prejavu. Jeho poézia-spev je o ničom a protežovanie sna, ktorý je zamieňaný s mystikou, robí z básnika hlupáka. Negáciou takéhoto prístupu je potom citovaná avantgardne ladená Olivova báseň na nasledujúcej strane časopisu. Inak je to najsurrealistickejšia báseň oboch ročníkov Prameňa. Neskorší významný nadrealista Vladimír Reisel tu síce uverejnil svoje básne Tuláci a Mŕtva, no sú to sylabotonické štvorveršia so striedavým rýmom, ktoré so surrealizmom nemajú vôbec nič spoločné.

Genéza Hlbinovej recepcie surrealizmu siaha do roku 1932, ked' voči nemu nebol až taký vyhranený. Tvrdil, že pravý surrealizmus zostáva intelektualizovanou mystikou. Takmer idealizoval. Rovnako bezproblémovo videl spojitost' medzi surrealistickou básnickou technikou a krest'anským svetonázorom. O ich spoločných znakoch uvažoval v Eláne v stati Bretonov surrealizmus a krest'anstvo: „Teda, ako vidíme, v podstate nemôže byt' ani reči o nejakom rozpore medzi surrealizmom, ako ho definuje Breton, a krestanským svetonáhl'adom. [...] Myslím, že surrealizmus práve má až mnoho spoločného s krestanstvom, lebo zdôrazňuje zázračnost' a slobodu“ (Hlbina 1935a). Hlbina názorovo vychádza z poznania Bretonovho manifestu surrealizmu, no podobne ako konštatoval neskôr pri Fabryho debute, ani prejavy surrealizmu v českej literatúre nehodnotí kladne: „Surrealizmus iba preto dostal trochu protináboženský náter, že väčšina surrealistov dosial'(ako aj u nás v Československu Nezval) s ním spojovala náladu protináboženskú “ (Hlbina 1935a). Protináboženský rozmer ešte viac preexponoval práve Fabry. Naopak, Olivova poézia Oblakov (1939) Hlbinovým úvahám neprotirečí. O tejto symbióze surrealizmu a krestanstva písal Hlbina v Eláne v januári 1935, ale už v májovom čísle v tom istom časopise proklamoval úplný opak vo vel'avravnom krátkom článku Surrealizmus mŕtvy pred narodením, v ktorom stručne recenzuje český preklad Bretonových Spojitých nádob a Nezvalovu Neviditel'nú Moskvu: „Zdalo sa, že v surrealizme je niečo kladného a môže sa ním dopredu pomknút vývoj svetovej poézie, ale Spojité nádoby úplne nás sklamali. 
Koketovanie surrealistov s marxizmom je len útek z prázdnoty. Breton sa honosí akoby kritizoval Freudovu psychoanalýzu, ale pritom do nekonečna omál'a jeho teóriu o sexualite a funkcii libida“ (Hlbina 1935d). L'avicový rozmer v súvislosti so surrealizmom pozoruje ako sekundárny - z núdze cnost'. Rovnako ho irituje okázalá sexualita, prítomná takisto vo Fabryho debute. Krátky text zakončuje strohou poznámkou, že surrealizmus patrí spolu s futurizmom do starého železa (Hlbina 1935d). Sériu antisurrealistických článkov v Eláne zakončil Hlbina polemickým textom na adresu Klementa Šimončiča, ktorý v Slovenských smeroch zavrhol Bremondovu koncepciu čistej poézie ako zaostalú v porovnaní so surrealistickou metódou. Šimončičov text bol, samozrejme, provokáciou, adresovanou najmä Hlbinovi. Šimončičovu antipatiu k spirituálnej poézii Hlbina ironizuje: „Slovom: mystika páchne náboženstvom a Bohom, preč s ňou! V století surrealizmu, ktorý nechce byt'len umeleckým smerom, ale svetonáhl'adom, sa predsa nebudeme zaoberat' takými pseudoproblémami a la tajomstvá, Boh, duchovnost'!“ (Hlbina 1936b). Napriek tomu je Hlbinovo záverečné konštatovanie ambivalentné: „Surrealizmus je chvíl'kový záchvat niekol'kých príslušníkov l'udského rodu. Charakterizuje ho pýcha, negácia, deštrukcia, satanizmus. Má okrem toho v sebe čosi dobrého, čo prevzal z tradície a čo ho spojuje s abbé Bremondom, prípadne s krestanstvom“ (Hlbina 1936b). V tejto súvislosti surrealizmus nezavrhuje z dôvodu svojej budúcej potenciálne surrealistickej tvorby, ale skôr pre už spomenutú mladú generáciu spirituálnych básnikov a Dilonga. Hlbina svoje taženie proti surrealizmu zakončil krátkym uštipačným textom v Postupe pod názvom Dav, surrealizmus a ja. V ňom reagoval na Mórica Mittelmanna Dedinského, ktorého posmešne nazýval Móric Mheschughe Dedinský: ,Ale spomenutý tovariš sa vel'mi mýli, ked' si myslí, že som oddaným sluhom kapitalizmu a buržoázie. Som práve tak za spravedlivé rozdelenie kozmického bohatstva ako on, lišime sa iba v tom, že on chce spasit' svet v mene Marxa a ja v mene Krista. On je viac za násilie, ja viac za lásku“ (Hlbina 1936a). Z textu vyplýva, že Hlbinovi prekážalo najmä povrchné preberanie surrealistických podnetov a plytkost' takejto tvorby domácich autorov: „Nuž o surrealizme sa u nás v ČSR (ovšem, že v Čechách) popísali také voloviny, že by nebolo divu, keby si l'udia začali pliest' pojem surrealizmu s pojmom blbosti. Naštastie mám po ruke Bretonov Manifeste de surrealisme, kde je to jasnejšie“ (Hlbina 1936a). Je očividné, že propagovanie surrealizmu v slovenskom kultúrnom prostredí nebolo jeho ambíciou. Seba vnímal ako zvestovatela Bremondovej koncepcie, preto v tomto čase usilovne prekladal jeho knihu Modlitba a poézia. Záverečná poznámka mala dokladovat' jeho nevôlu, nie neschopnost' vysvetl'ovat' surrealizmus na patričnej úrovni, ked'že podl'a vlastnej mienky Bretonov manifest vie on - na rozdiel od iných - v origináli nielen čítat', ale mu aj porozumiet'. Z dikcie tohto článku adresovaného Dedinskému si potom môžeme predstavit' podobu vyššie spomínaného Hlbinovho článku o Fabrym, ktorý Smrek odmietol publikovat'. Hlbinov postoj k surrealizmu nebol jednoznačne odmietavý ako neskoršie state J. Kútnika-Šmálova, ktorý vedno so surrealizmom kritizoval aj Hlbinu a jeho zbierky Dúha (1937) a Belasévýšky (1939), no formujúci sa surrealizmus (R. Fabry, M. M. Dedinský) sa stal naplnením Hlbinových obáv $\mathrm{z}$ nepochopenia a nesprávneho smerovania tejto avantgardy. 
Napriek tomu Hlbina vyhodnotil príval nových avantgardných smerov, najmä rozmach surrealizmu v polovici tridsiatych rokov, ako impulz k modernejšiemu a ešte objavnejšiemu tvarovaniu vlastnej básnickej tvorby, čo sa prejavilo hrou s rytmom, s rýmom a so slovami. Výsledkom týchto snažení je zbierka Dúha. Túto zmenu tvorivého prístupu predznamenal básnik teoretickým článkom, čo bolo pre neho charakteristické, tentoraz v českej katolíckej revue Akord. Základnú tézu svojej novej vízie prezrádza už nadpisom Poézia ako hra: „A preto báseň je tým dokonalejšia, čím má menej toho nečistého, čím má menej vedlajších tendencií a viac hudby, hry a vnútornej harmónie“ (Hlbina 1935b). Nečistou je ideológia, zataženie básne vopred deklarovanými tézami a hl'adanie účelnosti poézie, čo korešponduje so záverečnou častou článku, v ktorom Hlbina kritizuje Jána Poničana za jeho nepochopenie katolíckej moderny. Hlbina takto svoju zbierku Dúha obhájil už tri roky pred jej publikovaním: „Umenie samo sebou smeruje a vedie k Bohu a je iba pre Boha, ktorý je univerzálnym princípom každej formy a krásy. Pravá báseň a pravé umenie je vyjadrením l'udskej radosti z Božieho diela. Básnik a jeho čitatel' môžu túto radost' preživat' a kochat' sa v bezúčelnej nádhere, nič viac“(Hlbina 1935b). Vrcholom uvedených tendencií je prirovnanie takejto básne k Bohu: „V tom je práve dokonalost' poézie, že proste je, a to bez účelu, pretože má zmysel sama v sebe. Je do istej miery obrazom Boha, ktorý je čisté bytie a dokonalost' sama“ (Hlbina 1935b).V spojitosti s predošlými negatívnymi postojmi voči surrealizmu možno potom brúsenie rýmov v Dúhe interpretovat aj ako negáciu vol'ného nerýmovaného surrealistického verša, hoci táto motivácia sa v odbornej literatúre neuvádza. Ani V. Turčány v podrobnej analýze Dúhy v monografii Rým v slovenskej poézii (1975) nespomína túto pohnútku. On sám na nadrealizmus reagoval velmi podobne - podrealizmom (Tollarovič 2018b).

Oboznámenie sa s Hlbinovými literárnoteoretickými a estetickými názormi na literatúru osvetluje nielen jeho ustavičnú systematickú teoretickú prípravu, ale aj určité časové oneskorenie vo využití týchto postulátov vo vlastnej tvorbe. Tak ako „poéziu ako hru“ predstavil už v roku 1934 a naplno rozvinul až v zbierke Dúha, takisto s omeškaním predstavil spirituálnu lyriku v plnosti až v Ceste do raja, resp. v Harmonike, prostredníctvom tzv. kňazských básní, hoci o takejto poézii písal už pred vydaním debutovej zbierky, napr. v Eláne v článku O takzvanej absolútnej poézii (Hlbina 1931).

Po negatívnej skúsenosti s R. Brtáňom Hlbina odpovedal aj pomerne prísnym oddel'ovaním modernej poézie (básne Dúhy) a poézie primárne náboženskej, čo vo výsledku vzbudilo ešte väčší odpor v hodnotení Belasých výšok (1939) J. Kútnika-Šmálova. Po utíchnutí tzv. hlbinovskej aféry medzi Hlbinom a Brtáňom ukončil Hlbina tento spor pomerne rezignovane na stránkach Postupu: „Ak vydám nejakú zbierku veršov, najprv kritik zistuje moje náboženstvo, d'alej samozrejme zistí moje zamestnanie, povolanie, nervové dispozície, sexuálne sklony (Freud je v móde!), či moje čierne šaty konvenujú s tonalitou farieb užívaných v poézii (zistilo sa, že mám sklon k ružovosti!!) atd'. Beda mi, ked' sa bránim. Treba slušne mlčat'a trpiet"“ (Hlbina 1935c). Hlbina tak žiada, aby recenzentovi nezáležalo primárne na tom, že je katolíckym kňazom. Pri posudzovaní Hlbinovej tvorby to bolo fundamentálnym kritériom pre R. Brtáňa v prípade Harmoniky a neskôr pre J. Kútnika-Šmálova pri Dúhe a Belasých výškach. Dúha je Hlbinovou odpoved'ou na túto krivdu. 
Rudolf Dilong v citovanom liste Hlbinovi uštipačne odporúčal, aby svoju nasledujúcu zbierku vydal v Spolku sv. Vojtecha, pretože pre spolok pracoval. ${ }^{16}$ Bola to spolupráca na najväčšom projekte, ktorému sa v tridsiatych rokoch 20. storočia táto inštitúcia venovala. Dnes možno zhodnotit', že to bol jeden z vôbec najúspešnejších projektov tohto vydavatel'stva - zostavenie Jednotného katolíckeho spevníka. Hlavným zostavovatel'om bol Mikuláš Schneider-Trnavský, ktorý bol prácou na jeho príprave poverený už v roku 1921. Dielo vyšlo po prvýkrát tlačou v roku 1937. Odvtedy vyšlo v desiatkach vydaní a je dodnes každodenne používané pri katolíckych bohoslužbách. Spolupracovalo na ňom viacero komisií. Hlbina bol predsedom prozodickej komisie (Pöstényi 1937: 4), jej členmi boli Ivan Javor a Ladislav Hohoš. Jazykovú úpravu textov mal na starosti Anton Augustín Baník. Ked'že Schneider-Trnavský do spevníka prevzal mnohé piesne ešte z najstaršieho katolíckeho spevníka Cantus catholici (1655) a aj z iných nasledujúcich vydaní, Hlbina tieto texty prebásňoval a upravoval podl'a platnej jazykovej kodifikácie v miere určenej komisiou. Bola to náročná úloha, no pre Hlbinu znamenala nemalú poctu. Ako autor textu je uvedený pri dvoch piesňach. K obom skomponoval hudbu M. Schneider-Trnavský. Prvou je pomerne neznáma novoročná koleda Z neba prišiel k nám (Jednotný katolícky spevník 1937: 108). Jednoduchý a nenápaditý text bol zrejme objednávkou na novú pôvodnú novoročnú koledu pre tento spevník, čo vyžadovalo priame uvedenie nového roka: „Radujme sa, vesel'me sa, v novom roku tešíme sa: narodil sa nám mocný sveta Pán“ (Jednotný katolícky spevník 1937: 105). Druhý Hlbinov text je ovel'a známejší. Je to rozšírená a oblúbená pieseň spievaná na sväté prijímanie Ó, láska, nádej, spása (Jednotný katolícky spevník 1937: 278). Hoci v laickej verejnosti prevláda názor, že Schneider-Trnavský je skladatelom piesní spevníka, vo vel'kej väčšine je iba upravovatel'om piesní. Táto pieseň je však jednou z jeho najznámejších autorských piesní zložených pre daný spevník. Hlbinov text v porovnaní s ostatnými desat'ročia starými textami vyznieva pomerne moderne. Jedinečne, a ak v tomto prípade použijeme Hlbinov oblúbený výraz - mysticky, vyústuje prvá sloha piesne: „Za tebou, Bože, túžim jak v noci, tak vo dne; / ranami srdca svojho raň srdce dnes vo mne" (Jednotný katolícky spevník 1937: 267). Takéto autochtónne myšlienky nie sú pre texty tohto spevníka bežné. Hlbinova spolupráca na Jednotnom katolíckom spevníku je málo známa a, žial', ani nie príliš cenená kapitola Hlbinovej literárnej činnosti.

Už v čase distribúcie spevníka mu nevyplatili honorár, čo bolo opakovanie sa negatívnych skúseností za príspevky do časopisu Kultúra spred pár rokov. Zásadnejšie je v kontexte jeho literárnej činnosti však to, že Spolok sv. Vojtecha mu zamietol vydanie prekladu Bremondovej knihy Modlitba a poézia: „Vo veci Bremondovej práce Modlitba a poézia musím Vám tiež oznámit, že Spolok musí upustit' v tomto ohl'ade od d'alších podujatí." ${ }^{17} \mathrm{Z}$ listu vyplýva, že knihu Modlitba a poézia mal preloženú už začiatkom roka 1937, no napokon vyšla tlačou v Matici slovenskej až v roku 1943. Mimochodom, s vydaním Bremondovho prekladu nepochodil ani u Smreka, ktorý mu spolu s ním zamietol aj vydanie jeho vlastnej

16 R. Dilong v liste P. G. Hlbinovi, 9. november 1937. LA SNK, osobný fond R. Dilong, sign. 169 A 26.

17 List tajomníka SSV (podpis neidentifikovaný) P. G. Hlbinovi, 20. september 1937. LA SNK, osobný fond P. G. Hlbina, sign. 169 H 12. 
zbierky: „Viete, že ja by som vel'mi rád dával takéto knihy do našej Osvetovej knižnice, lebo sú to knihy priebojné a vel'mi ich potrebujeme. Ale obchodná stránka veci nám jednako nedovoluje vydávat' nateraz i takéto knihy. " 18 Bremondova Čistá poesie síce vyšla v českom preklade v roku 1935 s predslovom Františka Xavera Šaldu, no klúčové Bremondovo dielo Modlitba a poézia vyšlo iba v slovenčine (v češtine doposial' nie), a to práve zásluhou Hlbinovho prekladu v roku 1943, čo dodnes oceňujú i českí bádatelia (Kučerová 2017: 164), ked'že slovenský preklad bol distribuovaný aj do Čiech. Dá sa preto predpokladat', že o dielo by bol záujem aj v skoršom čase. Hlbina ponúkol Matici slovenskej preklad až koncom apríla 1943 a kniha vyšla už koncom toho istého roka, aj s autorskými právami a cirkevným schválením. Ihned' oslovila viacero básnikov a záujemcov o spirituálnu poéziu, napríklad čoskoro debutujúceho Jána Motulka. ${ }^{19}$

\section{Príčiny zmeny poetiky}

S ohl'adom na vyššie uvedené možno kategorickú zmenu básnickej poetiky P. G. Hlbinu vysvetl'ovat' ako sumár viacerých okolností a príčin: 1. vylúčenie z redakcie časopisu Postup a nespokojnost's jeho d'alším vývinom; 2. snaha o modernejší výraz vlastnej lyriky s dôrazom na pekný a originálny rým ako reakcia na volný nerýmovaný surrealistický verš; 3 . súperenie s Dilongom, ktorý v čase vydania prvých dvoch Hlbinových zbierok bol básnikom-ruralistom, no knihou Mladýsvadobník (1936) Hlbinu v napredovaní „predbehol“; 4. objavenie nového rozmeru Bremondovej koncepcie - poézia ako hra; 5. nespokojnost's východiskami posudzovania jeho tvorby literárnou kritikou (polemika s R. Brtáňom), čo Hlbinu priviedlo k pomyselnému rozdeleniu vlastnej tvorby na modernú (básne blízke zbierke Dúha) a náboženskú (napr. práca na Jednotnom katolíckom spevníku).

\section{Básnická zbierka Dúha v dobovej recepcii}

Vtedajši šéfredaktor Slovenských pohl'adov Stanislav Mečiar ocenil nový tón Hlbinovej poézie v recenzii Dúhy: „Ťažko by ste tu aj analyzovali jeho verš, nieto čo rozkladat', je to všetko také prosté, len nastavit' ucho, a stačíte všetko zachytit'. Nenáročný spev, jasný a sladký. Aj nám ho na čas zasa treba, ved' sme už privel'mi navykli v súčasnej poézii na mračné, hnilobné a úmrlčie sebapitvanie“ (Mečiar 1937). Súdobú poéziu zastupoval okrem iného aj surrealizmus. Spomínaná pochmúrnost' je signifikantným znakom Fabryho poézie. Eufonická zložka Hlbinovej poézie je tak Mečiarovi uspokojivou kvalitou pre túto básnickú zbierku. Zaujímavé je, že S. Mečiar nedáva verše do súvislosti s poetizmom, hoci tento domáci básnický smer propagoval v Eláne už v roku 1931.

Súvislost' so surrealizmom zasa radikálne vylúčil Klement Šimončič: „,Ak sa niekedy uvádza poézia Hlbinova v súvislosti so surrealizmom, je to komické nedorozumenie. Dnes slovo surrealizmus je skoro synonymné s revolučným činom v poézii. U Hlbinu nemôže byt' o tom ani reči“ (Šimončič 1937). Podobne ako S. Mečiar i on oceňuje určité odosobnenie Hlbinovej lyriky.

Dobové prijatie zbierky môžu ilustrovat' aj posudky dvoch mladých nádejných surrealistov, Vladimíra Reisela a Jozefa Paldiu. Reisel klasifikuje Hlbinovu 
dovtedajšiu spirituálnu poéziu ako tichú a pokojnú, ktorá mala niekde vyústit', no Dúha nie je vyústením, lež skrivenou cestou do slepoty (Reisel 1937). Vyčíta mu stratu originality vlastného výrazu: „Hlbina stratil svoje ja a vhupol do tmy, kde sa vecí možno iba dotýkat', ale nemožno zachytit' ich podstatu“ (Reisel 1937). Reisel očakával vyvrcholenie spirituálnej línie Hlbinovej tvorby, to však predstavujú zbierky Cesta do raja a Harmonika. To čo Hlbina považoval za novátorské-brúsenie rýmov, Reisel hodnotil ako úpadkové a prekonané. Reiselova dikcia je vel'mi príkra. Radostný a bezstarostný tón Hlbinovej poézie prezentuje ako tragédiu a dehonestáciu lyriky (Reisel 1937).

Vd'aka korešpondencii poznáme aj Hlbinovu reakciu: „Že to neni tak všetko pravda, ako si to tam V. Reisel vo svojej mládeneckej namyslenosti vybájil, dúfam, sami uznáte. [...] Nepotrebujem poučenie od nejakého maturanta,“20 uviedol v liste šéfredaktorovi Elánu J. Smrekovi a v závere dodal: „Dúfam, že sa nebojíte toho, že ma oblieha štekot surrealistických a socialistických šteniat. Však ony prestanú, nech si štekajú. Čakám aj zápornú odpoved' “"21 Z odpovede možno vyčítat', že odmietanie „pokrokovej“ mládeže mu bolo l'ahostajné, kritika kňaza J. Kútnika-Šmálova neskôr nie. Zápornú odpoved'očakával na svoju prosbu o vydanie básnickej zbierky. Napokon mu Belasé výšky vydal F. Urbánek.

Častý prispievatel'Prameňa Jozef Paldia, ktorého Hlbina kritizoval za sériu článkov o H. Gavlovičovi, publikoval aj recenziu Hlbinovej Dúhy v poslednom čísle tohto časopisu. Napodiv, tento text sa najviac zhoduje s neskoršími postrehmi literárneho vedca V. Turčányho v monografii Rým v slovenskej poézii (1975). Paldia, inak Dilongov epigón, autor zbierky Prsty nad riekou (1937), ako jediný z recenzentov kladie Hlbinovu zbierku do širšieho kontextu slovenskej poézie: "Jestli môžeme povedat', že Dilongovi patrí prvenstvo vo vychutnávaní novej poézie, Novomeskému v podaní a spracovaní námetu, Beniakovi v sile výrazu, tak istotne je Hlbina metaforickým podávatel'om najmarkantnejších rýmov. Jemné chvenie koncoviek slov, ktoré by ste inde považovali za otrelé, miznú pri krásne Hlbinových básni" (Paldia 1937a).

Tak ako recenzenti, ani Hlbina svoj príklon k poetizmu priamo nedemonštroval, a to z viacerých dôvodov. Poetizmus totiž vznikol v českom prostredí aj ako odpoved'na proletársku a moralizátorskú poéziu (Čepan 2002: 77). V slovenskom kontexte sa paradoxne spája práve s autormi proletárskej poézie, pričom na tento nepomer Oskár Čepan neupozorňuje pravdepodobne zámerne, s ohl'adom na dobu vzniku jeho charakteristiky poetizmu. Stanislav Šmatlák uvádza, že davistická literárna kritika (Jozef Rybák) zavrhovala poetizmus v zmysle jeho životného štýlu (Šmatlák 1971: 212). Ako dôvody boli uvádzané nulová sociálna angažovanost', absencia riešení sociálnych problémov, hedonizmus atd'. Tieto kritériá zohl'adňoval aj neskorší surrealista Vladimír Reisel v recenzii Hlbinovej zbierky. L'avicová kritika a davisti odmietli práve s ohl'adom na ne aj Novomeského Romboid (1932) či zbierku Fraňa Krála Balt (1931), no tieto diela boli v neskoršom období a sú takisto dnes označované za klúčové diela slovenského poetizmu.

20 P. G. Hlbina v liste J. Smrekovi, 5. január 1938. LA SNK, osobný fond Ján Smrek, sign. 181 F 3.

21 P. G. Hlbina v liste J. Smrekovi, 5. január 1938. LA SNK, osobný fond Ján Smrek, sign. 181 F 3. 
Básnickú zbierku Dúha Hlbina rozdelil na tri časti: Dúha, Preludy a Pohl'adnice. Prvá čast' obsahuje dvadsatštyri autonómnych básní, označených iba rímskymi číslicami. Exkluzivita výberu jazykových prostriedkov je recipientovi tejto Hlbinovej zbierky jasná už od prvých veršov. Profil celej básnickej zbierky pomocou metafory predstavil už na začiatku: „Hrá hudba v zámku, odkial'vanie / rytmus a vietor olifantom, / mrazivý refrén o nirváne / strašíjak dotieravý fantom" (Hlbina 1937a: 9). Výrazy hudba, rytmus a refrén sú klúčové slová, ktorými je predstavená zbierka už v úvodnej básni. Hudba nových niekol'koslabičných rýmov, rytmus štvorverší a refrénmi sú početné rýmové echá.

V. Turčány v Dúhe narátal až stodesat' cudzích slov v rýmovej polohe (Turčány 1975: 212). Zaujímavé sú však aj rýmové echá, ktorých je v zbierke asi stopätnást', pričom mnohé z týchto básnikových hier zasahujú okrem estetickej funkcie aj do významovej výstavby básne. Hlbina sa nechal inšpirovat' V. Nezvalom, J. Seifertom či K. Bieblom, ktorí sa v českej poézii snažili takmer vyčerpat' rýmové možnosti češtiny. Ked'že však tradícia podobného štýlu básnenia, ktoré spočíva v používaní viacslabičných rýmoviek, rýmových ech a kalambúrov, v slovenskej literatúre takmer neexistovala, ${ }^{22}$ nemal na čo nadväzovat'. V tomto zmysle ho slovenská literárna veda porovnáva s Hviezdoslavom.

V inej strofe prvej básne zbierky zasa prirovnáva svoj rýmový koncert k uragánu, orgiám a tanečniciam, ktoré ihned'sprevádza mariánsky motív: ,Uragan tanečníc, až hrôza, / orgie stvára na návrší, / pohliadni, mater dolorosa, / pohl'adom, ktorý hviezdy prší“ (Hlbina 1937a: 9). Mater dolorosa, teda Matka bolestná, je v nasledujúcom verši denominovaná už radostnejším motívom ako Hviezda ranná. V zbierke tak už na začiatku nachádzame určité provokujúce časti a alegórie. V citovanej druhej strofe čítame rým hrôza/dolorosa. Očakávali by sme tu rým rosa/dolorosa, aby vzniklo rýmové echo, verš by sa dal tomuto výrazu l'ahko uspôsobit'. Táto na prvý pohl'ad premárnená príležitost' básnika nadobudne zmysel v desiatom štvorverší tejto inak najdlhšej básne zbierky (tvorí ju šestnást' štvorverší): „Úsvite, počkaj, kto to spal tu / na bielych krídlach albatrosa, / kto slzy ronil do kobaltu, / koho to zrkadlila rosa?" (Hlbina 1937a: 10). Básnik tak ciel'avedome uspokojuje očakávanú túžbu po predpokladanom rýme v nasledujúcej časti básne. Takéto pomerne objavné rýmové koncovky sa v zbierke neopakujú a poet si zakladá na ich exkluzivite, no podobné nabádanie čitatel'a a vzbudzovanie očakávaní je jedným z tvorivých postupov tejto Hlbinovej poézie. Za pozornost' stojí aj prízvuk v citovanej strofe v rýme spal tu/do kobaltu, kde vzniká nový výraz alt - altu, čo značí hlboký ženský hlas.

Hlbina tak vlastne prechádza od eufónie založenej na asonanciách, konsonanciách a inej zvukomalebnosti, ktoré využil už v predošlej zbierke Harmonika (Tollarovič 2018a), k lexikálnym hrám založeným na cizelovaní rýmu. Predošlá hra so slovom a hravost', ktorou konkuroval L. Novomeskému, mu už nepostačovali, resp. otvorili mu nové možnosti, ktorých výsledkom je práca s rýmom. No nielen to. Už v tejto prvej básni označenej rímskou jednotkou (I.) ilustruje celú paletu jazykových hier, ktorú potom obmieňa v celej zbierke. Nezvyčajný je napríklad

22 Podobné tendencie však možno sledovat' aj u kňazských básnikov staršieho obdobia (napr. rým Dlhomíra Pol'ského skleróza/v skle Róza). 
homonymický rým odyseje/ódy seje a nasledujúca strofa: „Koreň tmy srdca na korene

/ šiel vždycky hlbšie celkom dolu, / mystické moje pokorenie / zostalo hrdé bez idolu“ (Hlbina 1937a: 11). Tu sa okrem rýmových ech kvázi svojvolne, bez ukotvenia v rýme, významovo zhodujú aj posledné slová druhého a tretieho verša: celkom dolu/pokorenie, čo korešponduje s vertikálnou obraznostou rýmovaných slov celkom dolu/bez idolu. Rovnako v poslednej strofe tejto prvej básne: „Na rieke záhrobia sa penia / najkrajšie slová ako smeti, / mystika vín a vykúpenia / do noci bledou lunou svieti“ (Hlbina 1937a:11). Rým penia/vykúpenia evokuje aj výraz vykúpe-vykúpat' sa, na čo jednak odkazuje aj slovo rieka z prvého verša štvorveršia a tiež odkazovanie vykúpenia $\mathrm{v}$ zmysle očistenia sa od niečoho, $\mathrm{v}$ tomto prípade od previnení.

V zbierke Harmonika, tiež čiastočne poetisticky ladenej, nebol Hlbinov jazyk ničím inovatívny a zvukomalebnost' pramení z akustického chápania verša ako celku. Navyše, repertoár slov je blízky 19. storočiu: kvetina, fialka, ruža, vták, motýl', potok, pole, spev, nebo, kaplnka, tátoš, čerešňa, škovránky, slávik atd'., všetko prítomné aspoň dva razy. V týchto básňach s poetickými výrazmi, ktoré už vtedy boli dávno prekonanými klišé, autor zvýrazňoval melodickost' verša. V Dúhe vidiet opačný postup, ide o cielavedomý výber takých jazykových prostriedkov, ktoré sa v dovtedajšej slovenskej poézii nevyskytovali, a ako upozorňuje V. Turčány, viac ako sto z nich je dokonca v rýmovej polohe.

V zbierke sú aj básne, v ktorých je rým jediným výraznejším nápadom, diktuje autorovi tempo a všetko ostatné je iba akousi výplňou, napríklad: „Krásavic vnady, / úkryty múk a zrady, / vidím vás žiarit'smutne / v bodke nad I. / Takisto ako Andrej Ady“ (Hlbina 1937a: 15). V strofe je všetko prispôsobené rýmovke „ady“ $\mathrm{v}$ trojakej podobe: ako koncovka podstatného mena v pluráli a singulári, pomocou fonetickej výslovnosti samohlásky a ako vlastné meno mad'arského básnika Endreho Adyho. Cudzie a málo časté výrazy však nečítame iba v rýmových polohách: „Moje sny smrtou tiahnu k raju / jaksprievod gejšíslnkom priodetý, / v ružových kimonách sa hrajú, / v náručí nesúc čerešňové kvety" (Hlbina 1937a: 16). Sprievod gejší a ružové kimoná i tak pútajú pozornost' čitatel'a, ked'že rým je v kontexte tejto zbierky ešte vel'mi nenápadný. Utíšením ,uragánu“ rýmov je báseň VIII.: „Ty dúha v oblakoch / do slnka oblečená, na nebo vzatá / z oltára v Bošáci!" (Hlbina 1937a: 18). Pri pozornej analýze možno dešifrovat, že ide o mariánsku báseň - v Bošáci je patrocínium kostola práve Nanebovzatiu Panny Márie. Dúha z titulu zbierky je teda Panna Mária, čo nik z recenzentov zrejme nepostrehol. Bošáca bola po Rosine druhým kňazským pôsobiskom, kde Hlbina kaplánoval ako mladý kňaz. Aj v predchádzajúcej zbierke Harmonika spomína svoje prvé kaplánske pôsobisko, obec Rosina pri Žiline (v básni Rosina), takisto s dôrazom na mariánsky kult: „Pondelok ráno idúc do Tura / navštívim vo Višňovom Pannu Máriu“ (Hlbina 1935b: 57). Hlbina tak v zbierkach predstavuje akýsi zemepis svojich pôsobísk.

Ako ukážková báseň zbierky Dúha bola už dobovými recenzentmi predstavovaná báseň s číslom X., konkrétne čast': „Ked'som šiel z Ilavy, / bol večer lilavý, / ozvena chichotu / rozbila ticho tu“ (Hlbina 1937a: 21). Podl'a nich tieto verše dokumentujú Hlbinovo nezmyselné hračkárenie, pritom motív cestovania po Slovensku a pohrávanie sa s vlastnými menami nie sú celkom nové. V predošlej zbierke Harmonika písal v básni Topolčany-Trnava-Bratislava podobne: „Stanica Trnava. / Láska je únava. [...] Stanica Bratislava. / Zbohom, mňa bolí hlava“ (Hlbina 1935b: 57). Kým v Harmonike boli podobné hry ojedinelé, v Dúhe 
sú fundamentom zbierky. Hlbina hl'adal rýmové echá nielen na cudzie slová, no tiež na slovenské vlastné mená (napr. na Púchov/lopúchov).

V zbierke možno z kompozičného hl'adiska nájst' dva typy básní. Celkom jednoduché, založené na akomsi diktáte rýmu, a potom tvorivejšie a menej prvoplánové, ktoré sú aj predmetom predloženej interpretácie. V básni XIII. sledujeme ustavičný pohyb smerom nadol-zostup: „Slnko dneska zemi / do náručia klesni, / svetlo tvoje znie mi / vo svadobnej piesni“ (Hlbina 1937a:24). Hoci je rým striedavý, sémanticky sa dotýkajú aj slová na konci po sebe nasledujúcich veršov: (k) zemi/klesni a tiež zvukové, evokujúce hudbu: znie mi/piesni. Z toho možno uzavriet', že ak sa v básni objaví jeden takýto netradičný a invenčný prvok, nie je osamotený a možno ich nájst' viac. Okrem kalambúru nemo dlieva/nemodlieva je pozoruhodný záver básne: „pime spolu per tu / krčah tmy a taju, / snenie pošlo kčertu, / piesne kolotajü“ (Hlbina 1937a:25). Tu sa rýmujú zasa prvé slová veršov: snenie/piesne a významovo sa dotýkajú pime/krčah.

Iným aspektom je návratnost' motívov v autorovej tvorbe. Biblického Samsona možno nájst' už v jeho časopiseckej ranej ponurej básni Už neposielajprorokov... V zbierke Dúha má motivická návratnost' symptomaticky hravú podobu: „Slepiačky tuším bolest', vyšši zásah, / Samson ti verí, milovaná Dalila, / stratil som oči v nevídaných krásach, / stĺp klesol, budova sa zvalila" (Hlbina 1937a: 29). Dvoja trojslabičná rýmovka sa zrkadlí s konsonanciou s na začiatku veršov. Tento postup nadobúda v porovnaní s predošlou Harmonikou (rovnako ako v prípade rýmu) novú kvalitu, pretože v nej sa podobné prvky vyskytovali v hraniciach verša, napr. rajská ruža v rozkvete; ružové ráno v Rosine; modlím sa mlčiac mocným mlčaním atd'.

V. Turčány uvádza iba jeden príklad na necitlivý zásah matičiarskeho korektora, ktorý takto poškodil Hlbinov rým: „Ach, vy prázdne masky, / čo z vás bude o rok, / prchajúce lásky, / zahrajme sa tarok..." Korektor tu podla jeho slov „opravil“" spojenie za rok na o rok, čím pokazil pôvodný Hlbinov rým za rok/tarok. Viacero najmä čechizmov v rýmovej polohe jazykový redaktor Matice, prirodzene, ponechal, no viacslabičná rýmovka mu v tom prípade ušla. Podobných zásahov je v zbierke viac. Našiel som minimálne jeden d'alší príklad: „Kým skúmam tento motiv / a robím analýzu, / vezie sto lokomotiv / na výlet Monu Lizu“ (Hlbina 1937a: 31). Je to exemplárny príklad Hlbinových mimoriadnych rýmov - dve rýmové echá $v$ jednom štvorverší, no domnievam sa, že korektor ochudobnil rým o jednu slabiku, teda zmenil Mona Lízu na Monu Lízu, a tak zanikla trojslabičná rýmovka analýzu/Mona Lízu.

Podobne netradične komponovaná je aj báseň XXI., ktorá je zasa bez rýmov: „Z tvojeho srdca stal sa cirkus, / papagáj hrá sa v lone odalisky, / v ružovom pásme s aureolou, / krotitel'delfínov je smutny“" (Hlbina 1937a: 35). Rozhodujúcim výrazom je cirkus, ktorý potom v básni konotujú papagáje, delfíny, šelmy, hady. V básni sú tiež náznaky surrealistickej techniky: „Noc jasná ako klavír, / noc ako katedrála, / jasmín a olej. / Krab na dne morskom / vo tme sa rozospieval. / Ked'vyšla luna, / kuny a lasice sa skryli“ (Hlbina 1937a:35). Možno sledovat' kauzalitu: klavír zo záveru prvého verša zaznie na konci piateho citovaného: klavír sa rozospieval. Dajú sa identifikovat' akoby aj skryté vnútorné rýmy v rámci veršov:jasná/jasmín alebo v podobe epanastrofy luna/kuna. Známa báseň XXIII. s incipitom Pre belasé sny a rýmovačky nadväzuje na autorovi vlastnú tradíciu sebapolemizujúcich básní: „Pre belasé sny a rýmovačky / hlúpo snívali sme, / myšlienok sme mali plné 
vačky / o surrealizme. / Abbé Bremond, obsypaný kvetmi, / v riši radovánok / dovolí iste pohl'ad letmý / na mystický vánok" (Hlbina 1937a: 37). Hlbina berúc do úvahy svoju predošlú proklamáciu Bremondovi ho tentoraz podobne prosí o omilostenie k novým básnickým hrám, ktorým zasvätil svoju zbierku: „Okúzleným tichom tvojím ja som, / na ostrove Java, / rozmarínom, snom a lásky jasom / spev nášrozvoniava“" (Hlbina 1937a: 37). Možnosti štvorveršia už autorovi nepostačujú, okrem kalambúrneho rýmu ja som/jasom a rýmového echa Java/rozvoniava je tu ešte vztah medzi spojením rozmarínom rozvoniava, a to dvojaký: olfatívny (čuchový) a tiež paronomázia daných slov. V poslednej básni cyklu Dúha rýmy opät' hýria obraznost'ou: „Belostná slonovina, / v ktorej sa túlite, / objaví lono vína, / slimáka v ulite" (Hlbina 1937a:38). Slonovina a lono vína možno čítat aj ako nádobu (lono) na víno zo slonoviny, používanú v antických časoch. Rovnako túlit'sa a ulita spája schúlenie, stiahnutie.

Druhá čast' zbierky nazvaná Preludy je utîšením „uragánu“ Dúhy. Ústrednými básňami sú Moja cesta a Slzy. V nich už básnik ovela menej silácky predstavuje piliere svojej tvorby, napríklad hudobnost prostredníctvom známeho klasicistického skladatel'a: „V postoji mnícha, milenca, / hl'adal som túžbe krásne mená, / plietol som slová do venca / $k$ fragmentom z Beethovena“ (Hlbina 1937a: 44). V predošlej zbierke Harmonika (1935) boli vyjadrením naplnenia Hlbinovej túžby po kňazstve tzv. kňazské básne, ked'že zbierka vyšla zakrátko po jeho kňazskej vysviacke. Hlbinovu poéziu necharakterizuje násilné verbálne zduchovnenie. Stále pomerne striktne oddeluje laické, civilné a sekulárne od kňazského, meditatívneho a spirituálneho, čo sa práve v tejto zbierke prejavilo najmarkantnejšie. Takmer celá zbierka je navonok sekulárna. Hlbinova báseň pokračuje: „Mystický cyklón zenitu / rozohnal plaché moje kroky. / Tieň chlapca hladám, neni tu. / Kde ste, vy detské roky?"“ (Hlbina 1937a: 44). J. Pašteka naznačil možnú inšpiráciu Hlbinovej tézy „poézia ako hra“ myšlienkou Romana Guardiniho (1885-1968) „liturgia ako hra“ (Pašteka 2002: 63), no úvahu už d'alej nerozvinul. Guardini v eseji $O$ duchu liturgie skutočne prirovnáva bohoslužobné obrady k hre, a to k hre malých detí: „Viděl jsi už někdy, s jakou vážností vymýšlejí děti pravidla pro své hry [...] jak se všichni musejí držet za ruce, co znamená tahle tyčka a tamten strom? To vše se zdá pošetilé pouze člověku, který netuší smysl toho všeho a který nedokáže vidět důvod určitého jednání v ničem jiném než v nějakém vykazatelném účelu“ (Guardini 1993: 36). Preto Hlbina otázkou „Kde ste, vy detské roky?" privoláva nenávratný čas detstva. V liturgii, pri bohoslužbe je takisto všetko predpísané a každý úkon má svoj zmysel a predpis: „anjelské svetlá a hlasy / chránia ma od náhody“ (Hlbina 1937a: 44), čo interpretujem ako liturgický poriadok. Jeho chvála vrcholí v poslednom štvorverší básne Moja cesta: „Vítam t'a blesk i paroma, / ty búrka ducha, zákon svätý, / vítam tvoj ozón, aróma: / otvorte kalich, kvety!" (Hlbina 1937a: 45). Poriadok je mu svätým zákonom a kalich kvetov je ako bohoslužobný kalich na víno. Básnik tak o kňazstve hovorí obrazne, hoci v Harmonike sa vyjadroval ešte jasnou rečou (napr. v básni $A$ mon amie inconnue): „Hostiu bielu premieňam na božské telo / a víno lásky na krv, cenu svojho neba" (Hlbina 1935b: 14). Kým v zbierkach pred kňazskou vysviackou túžil po kňazstve a v Harmonike pretvára svoju radost' z tejto služby na poéziu, v Dúhe sa kňazstvo už osmelil alegorizovat'. V Harmonike bolo všetko kňazské čierne ako reverenda (napr. v básni Pokorné odovzdanie): „Smutný môj život, čierny šat môj kňazský" (Hlbina 1935b: 66), no v Dúhe (v básni Ako v sne) 
sa stáva bielym ako kňazská alba: „Tento sen vždy miloval by / svojou láskou zápalistou, / ktorá z bielej smrti alby / k žitiu kriesi aj sen Kristov" (Hlbina 1937a: 59).

Pri kňazstve básnik zostáva aj v druhej zásadnej básni Slzy. V nej bilancuje svoju doterajšiu tvorbu: „Hl'adal som cestu k nebesám, / hl'adal som seba v liudskom slove, / sen mojej lásky vyšiel sám / nad hory fialové" (Hlbina 1937a: 46). V prvom verši je prvoplánovo ukrytý názov druhej zbierky Cesta do raja, no v pokore, ktorú symbolizuje pôstna fialová farba, básnik zistuje, že vlastné básnictvo bral možno až príliš vážne. Boha svojím dielom neohúri ani mu nič nepridá, stačí sa hrat', čo činí práve touto zbierkou. Opät to korešponduje s Guardinim, ktorého eseje Hlbina zaručene poznal: „Být před Bohem zaměstnán hrou, dílem umění - nikoli tvořit, nýbrž být, to je nejvlastnější podstata liturgie. Proto ta vznešená směs hluboké vážnosti a božského veselí, která je pro liturgii příznačná. Že liturgie tisícerými předpisy tak př́sně a pečlivě určuje, jaká mají být slova, pohyby, barvy, roucha, náčiní, to chápe jenom ten, kdo umí brát vážně umění a hru“ (Guardini 1993:36). Tieto Guardiniho názory však neboli v danom období v konzervatívnom slovenskom katolíckom prostredí poväčšine prijímané kladne. Až druhý vatikánsky koncil dal mnohým jeho návrhom za pravdu. Hlbina však v závere básne Slzy sám dospel k záveru, že takýto preexponovaný spôsob básnenia ho neuspokojuje a je mu bližšia tichá bremondovská modlitba: „Bojím sa svojich vlastných slov. / Ja hl'adám celkom tiché štastie. / Prestal ma bavit' prázdny lov / a žiadost'mlčat rastie“ (Hlbina 1937a: 47). Verše pôsobia ako výrazne autentické. Posledný citovaný verš je vážnou úvahou o ukončení básnickej tvorby. Napokon - básnikovo dlhé odmlčanie skutočne nastalo, a to počas druhej svetovej vojny.

V zbierke je tiež zopár dedikovaných básní: Vera ikon, istej W. Možno predpokladat' Veroniku, ked'že toto meno pochádza z gréčtiny v názve básne. Presne identifikovatel'ná je báseň Rajskej hviezde-H. F., venovaná Henny Fiebigovej, ktorú Hlbina tituloval práve pseudonymom z názvu básne. Privráva sa jej dokonca dôvernejšie než Dilong Helene Riasnickej v titulnej básni zbierky Helena nosí l'aliu (1935). Hlbina oslovuje Fiebigovú ako svoju princeznú a obdivuje jej snivú poéziu: „Šialený, opitý a možno blázon spola, / zbožňujem sen tvoj belasý. / Nad Tebou žiari božská aureola / zamilovaných do krásy" (Hlbina 1937a: 50). Pôsobivá je aj súhra posledných slov básne: zamilovaných do krásy s vlastným označením piráti krásy básnikov P. Olivu, J. Silana a M. Šprinca. Do svojho zoskupenia prijali aj Fiebigovú a nazvali ju „pirátka snov“. Hlbina tak v básni pojal snivost' i lásku ku kráse. Fiebigovú však ani týmto na nový pseudonym nepresvedčil. Rovnako nepresvedčivý je Hlbinov pokus o báseň podla Bretonovho surrealistického manifestu s názvom A la Breton. Zosmiešňujúci je záver básne: „tvoje telo hnedé a sladké / ako čokoláda Stollwerk, ktorú práve dávam do úst, / medzitým, čo pišem túto báseñ “ (Hlbina 1937a: 65). Sledujeme zvláštnu zhodu medzi Hlbinom a Fabrym. Kým Fabry v básňach preškrtnutého Prológu zbierky Ut'até ruky (1935) chcel dokázat', že je schopný vybrúsit pekný rým a písat'v sylabotonizme, Hlbina zasa niektorými básňami zbierky proklamuje svoju dispozíciu k surrealistickému veršu.

Pohl'adnice, záverečná čast' zbierky Dúha, obsahuje básne z Hlbinových ciest po Európe v roku 1936 (Bulharsko, Rumunsko, Turecko). Tieto básne umelecky nevynikajú, no dobovo boli populárne. Takmer každý básnik-cestovatel' zveršoval svoje vandrovačky. V rovnakom čase vydal rovnako nazvanú básnickú zbierku Fraňo Král' (Pohl'adnice, 1936), o desat'ročie skôr V. Nezval Básně na 
pohlednice (1926). Hlbina niektoré cesty absolvoval spolu s Dilongom. Ten týmto výletom venoval čast' zbierky Mesto s ružou (1939, mestom je Paríž), ktorú nazval Pät'kariet od mora a jedna z Paríža. Dilong pamätá na Hlbinu aj v ústrednej básni tejto zbierky Čo som chcel v Pariži: ${ }^{23}$ „Ale dnes Notre Dame tak dojíma ma / vstaň pokorená slávna republika / hl'ad'Francúz Boha s akou úctou vyká / pútničko krásna krásnych srdca úžin / v Ste Madeleine za vás tichú omšu slúžim / ked' Hlbina mi miništruje plačem / udivuje ma mnoho blizkych mračien" (Dilong 1939: 39). Počas predkoncilovej omše jeden kňaz slúžil omšu a druhý mu posluhoval - miništroval, čím Dilong podčiarkuje ich vzájomnú blízkost'. Dilong v básni pokračuje: „s Hlbinom hl'adim na tú polnoc prostú / jak Rimbaud driemem pod oblúkom mostu / druh jeho Verlaine za 5 frankov pije / ale druh jeho Verlaine nemocnýje / pá abbé Bremond hladíspoza chrámy / ten abbéovský klobúk váśje starý/vravte ste básnikje to epiteton / ako sa máte majstre André Breton“ (Dilong 1939: 40).

Hlbina v Dúhe ospravedlňoval svoj odklon od Bremonda heslom poézia ako hra, ktorý interpretoval ako posun, a nie odvrátenie sa od čistej poézie, a sám už v rámci zbierky v citovanej básni XXIII. načrtol polemiku so svojou hravo poňatou poéziou. Na druhej strane, Dilong Bremonda opúšta, pretože jeho „klobúk je už starý“. Jedným dychom zároveň pozdravuje „majstra André Bretona“. Dilongovo Mesto s ružou, ako aj nasledujúce zbierky Somnambul, Nevolaj, nevolaj (obe 1941) a Ktosi t'a volá (1942) sú zbierkami zapadajúcimi do kontextu slovenského nadrealizmu. Dilong sa podielal aj na zostavení nadrealistického zborníka Vo dne a v noci (1941). Práve v ňom v úryvku z memoárov $Z$ básnikovho denníka už celkom manifestačne zavrhol Henriho Bremonda: „Prestaňte pán abbé Bremond, so svojou abstraktnostou! Do najsubtílnejších vecí, ako je napr. poézia, prinášate samé nezmysly, čim tieto veci l'ud'om iba odd'alujete" (Dilong 1941:28). Hlbina sa Bremonda podobným spôsobom nevzdal a v nadrealistických zborníkoch nikdy nepublikoval. Dilong nezabudol na Hlbinu ani v závere pomerne krátkej básne Čo som chcel v Pariži , kde sa s ním stretáme už po tretíkrát: „do Lourdesu idem napozajtre zrána / v hoteloch ustal som jak stará panna / hotely sú jak oči Hlbinove / tu naraz cítim túžbu po domove“ (Dilong 1939: 41).

Dilongova báseň Čo som chcel v Pariž $i$ je autorovým osobným holdom Hlbinovi a uznaním jeho zásluh o novú spirituálnu lyriku. Nielen uznaním jeho vlastnej tvorby, ale aj časopisecky uverejnených prekladov, ved'nie náhodou v básni spomína francúzskych básnikov, ktorých Hlbina roky prekladal. Zároveň to možno vnímat' ako Dilongovo pozvanie Hlbinovi, ako podnet k surrealistickej tvorbe.

Dilongovu a Hlbinovu spoločnú cestu si všimol aj už spomínaný recenzent Dúhy Jozef Paldia. Venoval im báseň Dilong a Hlbina na cestách v zbierke Prsty nad riekou (1937): „Mali smútok na očiach a na ruke / a niesli sebou listy básnikov / večerali skoro všade bez vína / lebo víno posielali chudobným do mesta / títo dvaja Dilong Hlbina / išli do Francie na výstavu bez gesta" (Paldia 1937b: 41). Napriek rozdielnej poetike (Dilong - surrealizmus, Hlbina - poetizmus) ich mladá prichádzajúca generácia vnímala ako autority vystupujúce v jednote prostredníctvom rovnakých časopisov, vydavatel'ov atd'., no v d'alšej básni s názvom Dilong a Hlbina

23 Báseň je inšpirovaná Nezvalovou skladbou Edison. Je zaujímavé, že túto báseň neuvádza Pavol Winczer ako príklad tzv. elastickej slohy, hoci je Dilongovou najvydarenejšou básňou tejto kategórie (uvádza Dilongovu báseň Haluz na pokolení zo zbierky Helena nosí l'aliu, 1935). 
na vlne atlantickej už Paldia badá rozdiely: „Napríklad jeden z nich je decko a jeden starý otec" (Paldia 1937b: 43). Označenie Hlbinu, ktorý sa usiloval o nový výraz svojej poézie, za starého otca, pritom naznačuje, že v pohl'ade mladšieho básnika predstavoval Hlbina (oproti hravému Dilongovi) stále istý konzervatívny prvok.

S ohl'adom na dobovú situáciu slovenskej poézie Hlbinova zbierka Dúha (1937) nepriniesla nové podnety, je skôr vyvrcholením poetistických tendencií vo virtuóznej práci s jazykom a zošlachtovaním rýmu. V tejto spojitosti Hlbina nemal konkurenciu vo vtedajšej lyrike, a tak to neskôr konštatovala aj literárna veda. V. Turčány charakterizoval zbierku ako jednu z najpoetistickejších zbierok slovenskej poézie (Turčány 1975: 211). Rovnako ju vnímal Stanislav Šmatlák (Šmatlák 1971: 219), ktorý v druhom zväzku svojich autorských Dejín slovenskej literatúry hodnotenie rozvinul o prívlastok „,najartistnejšia zbierka autora“ (Šmatlák 2007: 322). Možno iba doplnit', že predošlé tri Hlbinove zbierky-Začarovaný kruh, Cesta do raja a Harmonika - sú reprezentatívnymi zbierkami katolíckej moderny a Dúha je zasa ukážkovou zbierkou slovenskej modifikácie poetizmu. V tomto ohlade dobová kritika neuznala Hlbinovu Dúhu a pokračovala v negatívnej recepcii aj v prípade autorovej nasledujúcej, piatej zbierky Belasé výšky (1939).

P. Winczer v štúdii o hravosti a hravých postupoch v slovenskej poézii podotkol, že práve V. Turčány klasifikoval poetistický rým ako vertikálny trópus, vertikálnu metaforu (Winczer 2000: 99). Túto tézu som sa snažil v tejto štúdii exemplárne demonštrovat' na Hlbinovej Dúhe, so zistením, že obstála Turčányho idea i Hlbinova zbierka. Doboví recenzenti však paradoxne nevenovali pozornost' rýmom a ich obraznosti, významom a konotáciám. Evidovali iba ich eufonickú zložku, sémantiku hl'adali mimo rýmu. Ked'že významová stránka bola jednoznačne podriadená eufonickej, paradoxne pútala pozornost' literárnej kritiky. Tento $\mathrm{z}$ dnešného pohl'adu alogický postup je v prípade takých renomovaných kritikov, akými boli J. Kútnik-Šmálov alebo Jozef Felix, tažko pochopitel'ný, ked'že kontext českého poetizmu im nebol neznámy. Preto je v ich prípade absencia čo i len náznaku komparácie Hlbinovej poézie s Nezvalovými básňami zarážajúca a najmä poškodzujúca Hlbinu, pretože jeho nová tvorba bola vlastne $\mathrm{z}$ ich strany interpretovaná ako anachronizmus. S ohl'adom na tabuizovanie katolíckej moderny v čase vzniku Turčányho a Winczerových štúdií je ich dodatočná reflexia Hlbinovej poézie v týchto súvislostiach ešte cennejšia. Zároveň ich výber tohto zakladatel'a katolíckej moderny pripisuje Hlbinovej poézii závažnost' aj v širších súvislostiach slovenskej poézie tridsiatych rokov 20. storočia.

\section{Archívne pramene}

Slovenská národná knižnica v Martine, Literárny archív, osobné fondy: Rudolf Dilong, Pavol Gašparovič Hlbina, Ján Smrek

\section{Pramene}

DILONG, Rudolf, 1939. Mesto s ružou. Modra: Teodor Mesík.

DILONG, Rudolf, 1941. Z básnikovho denníka. In Vo dne a v noci. Bratislava: Skarabeus a FKM, s. 27-28.

HLBINA, Pavol Gašparovič, 1931. O takzvanej absolútnej poézii. Elán, roč. 2, č. 4, s. 7. HLBINA, Pavol Gašparovič, 1934a. Anketa o poézii. Postup, roč. 1, č. 7, s. 7. 
HLBINA, Pavol Gašparovič, 1935a. Bretonov surrealizmus a krestanstvo. Elán, roč. 5, č. 5, s. 4. HLBINA, Pavol Gašparovič, 1935b. Harmonika. Praha: L. Mazáč.

HLBINA, Pavol Gašparovič, 1935c. Niekol'ko bodov. Postup, roč. 2, č. 5-6, s. 184.

HLBINA, Pavol Gašparovič, 1935d. Surrealizmus mútvy pred narodením. Elán, roč. 5, č. 9, s. 7. HLBINA, Pavol Gašparovič, 1936a. Dav, surrealizmus a ja. Postup, roč. 2, č. 1, s. 32.

HLBINA, Pavol Gašparovič, 1936b. Henri Bremond a surrealisti. Elán, roč. 6, č. 7, s. 7. HLBINA, Pavol Gašparovič, 1936c. Janko Silan: Kuvici. Prameň, roč. 1, č. 8, s. 199.

HLBINA, Pavol Gašparovič, 1936d. Rudolf Fabry: Utaté ruky. Prameň, roč. 1, č. 1, s. 23.

HLBINA, Pavol Gašparovič, 1937a. Dúha. Turčiansky Sv. Martin: Matica slovenská.

HLBINA, Pavol Gašparovič, 1937b. Surrealistické zátišie. Prameň, roč. 2, č. 9, s. 206.

JEDNOTNÝ katolícky spevník, 1937. Trnava: Spolok sv. Vojtecha.

LETKO, Ján, 1934. Tančiaca spravedlivost'. Postup, roč. 1, č. 4, s. 4-5.

MEČIAR, Stanislav, 1937. Pavel G. Hlbina: Dúha. Slovenské pohl'ady, roč. 53, č. 10, s. 590.

OLIVA-UŠÁK, Pavol [OLIVA, Pal'o], 1937. Panne. Prameň, roč. 2, č. 9, s. 207.

PALDIA, Jozef Arnold, 1937a. P. G. Hlbina: Dúha. Básne. Prameň, roč. 2, č. 9, s. 220-221.

PALDIA, Jozef Arnold, 1937b. Prsty nad riekou. Malacky: Gavlovičov študentský samovzde-

lávací krúžok.

POGORIELOV, Alexander, 1934. Júnový dážd'. Postup, roč. 1, č. 4, s. 2.

PÖSTÉNYI, Ján, 1937. Prívet. In: Jednotnýkatolícky spevník. Trnava: Spolok sv. Vojtecha, s. 3-5. REISEL, Vladimír, 1937. Nová zbierka Hlbinova. Elán, roč. 8, č. 4, s. 9.

ŠIMONČIČ, Klement, 1937. Poznámky k cestám slovenskej poézie. Slovenské smery, roč. 5 , č. 1, s. 72.

VO DNE a v noci, 1941. Bratislava: Skarabeus a FKM.

ZMENA redakcie, 1934. Postup, roč. 1, č. 3, s. 11.

\section{Literatúra}

BOKNÍKOVÁ, Andrea, 2017. Potopené duše. Bratislava: Aspekt.

BRUNCLÍK, Jozef, 2017. Introvertnostou ku katarzii. Lyrickýsvet v tvorbe Jána Motulka. Nitra:

Univerzita Konštantína Filozofa, Filozofická fakulta.

ČEPAN, Oskár, 2002. Literárne dejiny a literárna veda. Bratislava: Veda.

GUARDINI, Romano, 1993. O duchu liturgie. Praha: Česká křestáanská akademie.

KAMENČÍK, Marián, 2019.Z Hlohovca do Honolulu a spat'. Hlohovec: Ex libris ad personam.

KUČEROVÁ, Vendula, 2017. Srovnání některých aspektů díla Janka Silana a Jana Kameníka.

In RudolfDilong a stredoeurópska katolícka literatúra. Nitra: Univerzita Konštantína Filozofa,

Ústav stredoeurópskych jazykov a kultúr, s. 167-176.

PAŠTEKA, Július, 2002. Tvár a tvorba slovenskej katolíckej moderny. Bratislava: Lúč.

ŠMATLÁK, Stanislav, 1971. 150 rokov slovenskej lyriky. Bratislava: Tatran.

ŠMATLÁK, Stanislav, 2007. Dejiny slovenskej literatúry II. Bratislava: LIC.

TOLLAROVIČ, Peter, 2018a. Harmonika v súzvuku poetistickej hravosti a postulátov katolíckej moderny. In Spirituálne zlomky. Bratislava: Univerzita Komenského, s. 62-92.

TOLLAROVIČ, Peter, 2018b. Podrealizmus. In Spirituálne zlomky. Bratislava: Univerzita Komenského, s. 93-106.

TURČÁNY, Viliam, 1975. Rým v slovenskej poézii. Bratislava: Veda.

WINCZER, Pavol, 2000. Súvislosti v čase a priestore. Bratislava: Veda.

Mgr. Peter Tollarovič, PhD.

Studia Academica Slovaca

Filozofická fakulta Univerzity Komenského

Gondova 2

81109 Bratislava

Slovenská republika

E-mail: peter.tollarovic@uniba.sk 